\title{
The Potential of Galangal (Alpinia galanga Linn.) Extract against the Pathogens that Cause White Feces Syndrome and Acute Hepatopancreatic Necrosis Disease (AHPND) in Pacific White Shrimp (Litopenaeus vannamei)
}

\author{
Tidaporn Chaweepack ${ }^{1}$, Boonyee Muenthaisong ${ }^{1}$, Surachart Chaweepack ${ }^{1} \&$ Kaeko Kamei $^{2}$ \\ ${ }^{1}$ Chanthaburi Coastal Fisheries Research and Development Center, Department of Fisheries, Muang, Chanthaburi, \\ 22000, Thailand \\ ${ }^{2}$ Department of Biomolecular Engineering, Kyoto Institute of Technology, Matsugasaki, Sakyo-ku, Kyoto \\ 606-8585, Japan \\ Correspondence: Tidaporn Chaweepack, Chanthaburi Coastal Fisheries Research and Development Center, \\ Department of Fisheries, Muang, Chanthaburi, 22000, Thailand. Tel: 66-3945-7987-8. E-mail: \\ tidaporn2513@gmail.com
}

Received: March 21, 2015 Accepted: April 2, 2015 Online Published: April 25, 2015

doi:10.5539/ijb.v7n3p8

URL: http://dx.doi.org/10.5539/ijb.v7n3p8

\begin{abstract}
White feces syndrome and acute hepatopancreatic necrosis disease (AHPND) are serious diseases that have recently been noted in Pacific white shrimp (Litopenaeus vannamei). Vibrio bacteria and 6 species of fungi (Aspergillus flavus, A. ochraceus, A. japonicus, Penicillium sp., Fusarium sp., and Cladosporium cladosporioides) were isolated from shrimp naturally infected with white feces syndrome. Antibiotics have been used to treatment the disease for many years, but these have been ineffective and have resulted in drug residue problems for the shrimp industry. In this study, an alternative method was tested for its efficacy in controlling these pathogens. The crude extract of galangal (Alpinia galanga Linn.), an herbal medicine, inhibited the growth of 8 vibrio species of the pathogen, V. parahaemolyticus (EMS/AHPND) in particular. The results also showed that $0.5 \mathrm{mg} / \mathrm{ml}$ of the galangal extract was a concentration that produced the strongest inhibition of the fungi A. ochraceus. Naturally infested shrimp L. vannamei were fed 2 and $4 \%(\mathrm{v} / \mathrm{w})$ portions of the herb extract for 12 days and their progress was compared with that of a control group (no herb extract). At the end of the feeding trial, the numbers of total Vibrio spp. and the incidence of fungi infestation in the hepatopancreas and intestines of treated shrimp were significantly lower than that in the control group $(P<0.05)$. Furthermore, the survival rates for the treatment groups, after injections with $V$. parahaemolyticus (EMS/AHPND), were significantly higher than that of the control group $(P<0.05)$. Based on these results, we can report that the galangal extract has antimicrobial properties that are applicable as bio-medicinal agents against white feces syndrome and AHPND. Therefore, in the future this herb should be an alternative to chemotherapeutic agents that are being used in the shrimp industry.
\end{abstract}

Keywords: galangal, Alpinia galanga Linn., Vibrio spp., V. parahaemolyticus EMS/AHPND, fungi, Litopenaeus vannamei

\section{Introduction}

Disease outbreaks caused by viruses, bacteria and protozoa are important disease agents within the shrimp aquaculture, a major industry in Southeast Asia, because they can lead to serious economic losses for long periods of time. These bacterial disease pathogens have grown rapidly due to global warming, which has stressed the shrimp population by reducing immunity and enhancing the infection rates. In 2009, the first reports of an emerging disease in Penaeus sp. shrimp was initially named Early Mortality Syndrome (EMS) in China. This disease was later referred to as Acute Hepatopancreatic Necrosis Disease (AHPND). In 2011, EMS/AHPND occurred frequently in Vietnam, which led to the isolation of the causative agent, $V$. parahaemolyticus (Tran et al., 2013). In 2012, AHPND had a major impact on shrimp farmers in Thailand and Southeast Asian who sustained heavy losses in production (Flegel, 2012; NACA-FAO, 2011). Outbreaks of disease reported in Thailand during 2010-2011 called White feces syndrome were found mostly in Pacific white shrimp (L. vannamei). Infestations of Gregarine protozoa and Vibrio bacteria have been found that caused loose shells, 
decreased appetite, retarded growth, and finally sporadic mortality of the shrimp in grow out ponds. Typical symptoms of the disease can be noted by white feces floating on the water surface in the rearing pond (Tangtrongpiros, 2010). Several reports have shown that vibrio bacteria including $V$. alginolyticus, $V$. cholerae, $V$. parahaemolyticus, $V$. vulnificus, $V$. mimicus, and $V$. harveyi are the important pathogens, as these are always isolated from diseased L. vannamei (Lighter, 1993; Vandenberghe et al., 1999; Montero \& Austin, 1999). Bacterial pathogens can cause problems that range from growth retardation to sporadic mortalities and mass mortalities of shrimp. From this point of view, vibrio bacteria represent the greatest bacterial threat to the shrimp industry. When shrimp are under stressful conditions, such as when they are reared in a high-density setting, their immunity is lowered. Under those conditions, vibrio bacteria easily attack, which leads to the occurrence of disease (Ruangpan et al., 1997; Sung et al., 2001; Karunasagar et al., 2004; Lee et al., 2009). Some aquatic fungi are also opportunistic pathogens. Fusaruosis or black gill disease is caused by Fusarium spp., and it may affect all developmental stages of penaeid shrimp (Karunasagar et al., 2004). Shrimp farmers have few choices to control the diseases that threaten their shrimp production. Many types of drugs and chemicals have been used to treat vibrio bacteria, and this has created a residual drug problem that has led to the spread of drug-resistant bacterial strains in the shrimp industry. To solve these problems, medicinal herbs have been introduced as alternative methods for the control and treatment of bacterial diseases, because herbs are known to have anti-parasite and antimicrobial effects. Galangal (Alpinia galanga Linn.) is one of the typical herbs that can be used for the treatment of diseases in shrimp, and it is available year-round at a low cost. This herb is rich in phenolic compounds such as flavonoids and phenolic acids (Mayachiew \& Devahastin, 2008). The essential oil of the crude galangal extract is responsible for its antimicrobial activity (de Pooter et al., 1985; Turker et al., 2002; Oonmetta-areea et al., 2006; and, Rao et al., 2010). Therefore, we tested the potential efficacy of an ethanol galangal crude extract to inhibit and reduce the number of Vibrio spp. bacteria and fungi in natural infestations of white feces syndrome and AHPND in Pacific white shrimp (L. vannamei).

\section{Materials and Methods}

\subsection{Preparation of Galangal-Ethanol Extract}

Fresh galangal rhizomes were purchased from a local market in Chanthaburi, Thailand. The rhizomes were sliced into thin layers and dried at room temperature in a tray dryer followed by heating at $45^{\circ} \mathrm{C}$ for $24 \mathrm{~h}$. After drying, they were ground into powder using an electric blender (Philips, Cucina, Thailand). Ten grams of the galangal powder were suspended in $100 \mathrm{ml}$ of ethanol, and then let stand at room temperature overnight. After filtration through filter paper (No. 1, Whatman International Ltd., Maidstone, UK), the extract was dried in a rotary evaporator (Rotary Evaporator BUCHI R-114, Vacuum pump BUCHI B-169 Switzerland) (Oonmetta-aree et al., 2006).

\subsection{Isolation and Identification of Bacteria}

Pathogenic Vibrio species that included V. cholerae, V. parahaemolyticus, V. parahaemolyticus (EMS/AHPND), $V$. fluvialis, $V$. vulnificus, V. alginolyticus, V. mimicus, and $V$. harveyi were isolated from diseased Pacific white shrimp (L. vannamei) obtained from grow-out ponds in Chanthaburi Province, using the Ruangpan \& Kitao (1991) method. The isolate was streaked on Thiosulfate Citrate-Bilesalt Sucrose Agar (TCBS Agar, Difco USA) for selective isolation of Vibrio, and cultivated at $30^{\circ} \mathrm{C}$ for $18-24 \mathrm{~h}$. The Vibrio species was identified according to a scheme developed by Colwell (1984) using API 20E kits (ATB System, BioMérieux, France) and the PCR technique for the detection of V. parahaemolyticus (EMS/AHPND) (Joshi et al., 2014).

\subsection{Bacterial Inoculum}

The isolate was streaked on TCBS agar and incubated at $30^{\circ} \mathrm{C}$ for $18-24 \mathrm{~h}$. A pure colony was streaked on Trypticase Soy Agar (TSA, Difco, USA), and incubated at $30^{\circ} \mathrm{C}$ for $18-24 \mathrm{~h}$. Several colonies of bacteria were inoculated into a $1.5 \%$ sterile sodium solution, which was mixed well with a vortex mixer. The bacterial suspension was tested using McFarland Standard No. $0.5\left(\times 10^{8} \mathrm{cfu} / \mathrm{ml}\right)$ then diluted to $\times 10^{6} \mathrm{cfu} / \mathrm{ml}$ for antibacterial activity testing.

\subsection{Disc Diffusion Test}

The efficacy of herbs for the growth inhibition of Vibrio was done using an agar disc diffusion assay and efficacy testing method developed by Oometta-aree et al. (2006). The Vibrio inoculums $\left(\times 10^{6} \mathrm{cfu} / \mathrm{ml}\right)$ were spread on Mueller Hinton agar (Difco, USA) supplemented with $1.5 \% \mathrm{NaCl}$ (MHA-1.5\% NaCl), and then kept for about 5 $\mathrm{min}$ to allow the surface of the agar to dry. Each herb extract $(80 \mu \mathrm{l})$ was applied to a paper disc ( $\Phi 8 \mathrm{~mm}$, Advantec, Tokyo, Japan) then both sides were dried in a sterile laminar flow. The paper disc was then placed onto an MHA$1.5 \% \mathrm{NaCl}$ plate inoculated with Vibrio, followed by incubation at $30^{\circ} \mathrm{C}$ for $18-24 \mathrm{~h}$. The efficacy of herbs for the growth inhibition of Vibrio was estimated by measuring the diameter of the clear zone surrounding the herbal disc. 


\subsection{Minimum Inhibitory Concentration (MIC) Test}

One milliliter of Vibrio $\left(\times 10^{6} \mathrm{cfu} / \mathrm{ml}\right)$ was inoculated into liquid Mueller Hinton broth containing $1.5 \% \mathrm{NaCl}$ (MHB-1.5\% NaCl). Each herbal extract $(0.25 \mathrm{~g} / \mathrm{ml})$ was diluted with ethanol using a 2-fold dilution method. In this method, $160 \mu \mathrm{l}$ of each dilution was dropped onto a paper disc ( $\Phi 8 \mathrm{~mm}$, Advantec, Tokyo, Japan), followed by drying in a sterile laminar flow. Then the paper disc was placed into a MHB-1.5\% NaCl liquid medium and incubated at $30^{\circ} \mathrm{C}$ for $18-24 \mathrm{~h}$. The MIC of ethanol extract was regarded as the lowest concentration of the extract in the liquid medium that would permit no turbidity of the tested microorganism (Oometta-aree et al., 2006).

\subsection{Minimum Bactericidal Concentration (MBC) test}

The tubes that showed no turbidity of the bacteria and the last tubes showing turbidity from the MIC test were used for further MBC testing. Then, $0.1 \mathrm{ml}$ of culture medium used in the MIC test was spread onto TCBS Agar (Difco, USA), incubated at $30^{\circ} \mathrm{C}$ for $18-24 \mathrm{~h}$, and the formations of colonies were counted. The $\mathrm{MBC}$ was the lowest concentration of herbal extract that formed less than 20 colonies, corresponding to an inhibition of the bacterial growth at $99.9 \%$, or more (Oometta-aree et al., 2006).

\subsection{Efficacy of the Galangal Extract against Pathogenic Fungi}

\subsubsection{Fungi Isolation and Identification}

The samples of naturally infected shrimp were collected from 50 grow-out ponds. Artificial feed was simultaneously collected for use in rearing shrimp samples. Fungi were isolated from the hepatopancreas and intestines of diseased shrimp and artificial feed were cultured on Glucose - Yeast in seawater (GYS) agar then incubated at $25-27^{\circ} \mathrm{C}$ for $2-5$ days (Khomvilai, 2006). Several isolation samples were streaked on GYS agar until the fungus had formed a pure culture. Then the isolations were identified by the National Center for Genetic Engineering and Biotechnology, Thailand, as described by Klich (2002), Raper \& Fennell (1965) and by Samson et al. (1994 \& 1995).

\subsubsection{Fungi growth Inhibition Test}

The galangal crude extract was dissolved with sterilized seawater in 8 dilutions: $0.0005,0.005,0.05,0.5,1,2,4$ and $8 \mathrm{mg} / \mathrm{ml}$. Agar plates of pure fungus were cultured for normal growth. Each fungus colony was cut into a 1 $\mathrm{cm}$ diameter using a cork border and was immersed in each galangal extract dilution for 3 replications. The treatment group was exposed to each extract dilution for 30 minutes, then incubated at $25^{\circ} \mathrm{C}$, and the control group was immersed in sterilized seawater. After the fungi had been completely immersed, the fungi plugs were cleaned twice in sterilized seawater and placed on GYS agar followed by incubation at $25-27^{\circ} \mathrm{C}$. After incubation for 2 days, the fungi colony diameters from each plate were measured. The efficacy of the crude extract against growth inhibition was established by comparing the diameters of the colony radii of the fungal mycelia of the treatment and control groups, which was calculated as follows:

$$
\begin{array}{r}
\text { Colony radius growth rate }(\%)=\frac{\text { (colony radius of the treated fungus) }}{\text { (colony radius of the control) }} \times 100 \\
\text { The growth inhibition of fungi }(\%)=100-\text { Colony radius growth rate (\%) } \\
2.8 \text { Effect of the Galangal Extract against Vibrio spp. Bacteria and Fungi in L. vannamei }
\end{array}
$$

\subsection{Effect of the Galangal Extract against Vibrio spp. Bacteria and Fungi in L. vannamei}

\subsubsection{Test Diets}

The galangal extract was dissolved in ethanol to a concentration of $0.25 \mathrm{~g} / \mathrm{ml}$, then was mixed with commercial pellet feed (CP feed, Thailand) at $2(5 \mathrm{~g} / \mathrm{kg}$ diet $)$ and $4 \%(10 \mathrm{~g} / \mathrm{kg}$ diet $)$. For the control group, no herbal extract was added. The feed was kept at room temperature for $30 \mathrm{~min}$ to allow the absorption of the extract and the evaporation of the ethanol. The control diet was also absorbed with ethanol, and then evaporated. Next, the pellets were coated with squid fish oil (Agrithai And Development Co., Ltd., Thailand) at $10 \mathrm{~g} / \mathrm{kg}$ feed to prevent the dispersion of the galangal extract in water and to reduce the smell of the extract. The feed was then dried at room temperature. These tested diets were prepared for shrimp each day. The feeding rate was $3.0 \%$ of the shrimp body weight.

\subsubsection{Treatment of Pathogenic Vibrio Bacteria and Fungi}

About nine hundred white feces syndrome diseased shrimp, L. vannamei, with average body weight $10.7 \pm 1.6 \mathrm{~g}$ were obtained from a shrimp farm in Chanthaburi Province, Thailand. The samples were acclimatized for 3 days in 3 plastic tanks, each with a capacity of 500 L. Then, the number of Vibrio spp. bacteria and fungi in the hepatopancreas and intestines of 15 shrimp were examined and recorded. Experimental aquariums (90 L capacity) were filled with $70 \mathrm{~L}$ of chlorine-treated $29 \mathrm{ppt}$ seawater. Flow-through water equipped with an aeration system was 
arranged. Each group of 25 shrimp was sampled from the stocked tanks and was transferred into the individual experimental aquariums for 5 replications of treatment and the control group. The shrimp were fed the test diet 3 times a day for 12 days. Excess feed and waste was removed before each feeding. The parameters of the water were maintained for optimal quality. Three shrimp were sampled at $1,3,5,7,10$, and 12 days from each aquarium after the feeding trials. The hepatopancreas and intestines of the shrimp were examined for Vibrio spp. and fungi via the spread-plate method.

$$
\text { Incidence of fungi infestation }(\%)=\frac{\text { The number of infested shrimp }}{\text { Total number of observed shrimp }} \times 100
$$

\subsection{Effect of the Extract on Disease Resistance Caused by Vibrio spp.}

\subsubsection{Preparation of the Bacterial Samples}

The pathogenic $V$. parahaemolyticus (EMS/AHPND) was isolated from infected shrimp. This bacterium was identified based on a scheme established by Colwell (1984) using API 20E kits (ATB System, BioMérieux, France). Identification of $V$. parahaemolyticus (EMS/AHPND) was accomplished via the PCR technique (Joshi et al. 2014). The isolate was grown on Thiosulfate Citrate Bile Sucrose Agar (TCBS Agar, Difco USA) incubated at $30{ }^{\circ} \mathrm{C}$ for $18-24 \mathrm{~h}$. Then a pure colony was streaked on Trypticase Soy Agar (TSA Difco, USA), and incubated at $30^{\circ} \mathrm{C}$ for $18-24 \mathrm{~h}$. Heavy streaks of isolated bacteria were inoculated into a $0.85 \%$ sterile sodium solution, which was then mixed well via a vortex mixer. The bacterial suspensions were tested using McFarland Standard No. $0.5\left(10^{8} \mathrm{cfu} / \mathrm{ml}\right)$ then diluted to $10^{5} \mathrm{cfu} / \mathrm{ml}$ for the antibacterial activity test.

\subsubsection{Resistance Test}

The water in the $90 \mathrm{~L}$ aquariums was managed according to the method mentioned above. Triplicate aquariums were prepared for each group. Ten shrimp $(10.7 \pm 0.8 \mathrm{~g} / \mathrm{shrimp})$ were transferred to each aquarium for 2 treatment groups ( 2 and $4 \%$ of the extract diet) and 1 control group ( $0 \%$ of the extract diet). The shrimp were fed test diets 3 times a day for 12 days. After the shrimp were fed a treated diet for 12 days, disease resistance tests were conducted via the injection of $100 \mu \mathrm{l}$ of bacterial suspension, V. parahaemolyticus $\left(2.85 \pm 0.63 \times 10^{5}\right.$ $\mathrm{cfu} / \mathrm{ml}$ ), into the abdominal segment. After injection, shrimp were fed a commercial diet twice a day for 15 days. Disease symptoms and mortality rates were observed and recorded daily; the surviving shrimp were counted, and statistical analysis was calculated after the end of the experiment.

\subsection{Statistical Analysis}

A multiple comparison (Pair wise Comparison Test: Fisher's LSD) test was used to examine the significant differences $(\mathrm{P}<0.05)$ among treatments and control groups using SYSTAT VERSION 5.0.

\section{Results}

\subsection{Antibacterial Activities of Galangal Extract}

Table 1. Growth Inhibition zones, Minimum Inhibitory Concentration (MIC) and Minimum bactericidal Concentration (MBC) by the galangal extract to 8 species of Vibrio spp.

\begin{tabular}{lccccc}
\hline \multirow{2}{*}{\begin{tabular}{l} 
Vibrio spp. \\
\cline { 2 - 5 }
\end{tabular}} & \multicolumn{2}{c}{ Growth inhibition zone $(\mathrm{mm}$.) } & MIC & MBC & Sensitivity of bacteria \\
\cline { 2 - 5 } V. cholerae & $31.0 \pm 0.5$ & $0 \pm 0$ & 0.15 & 0.15 & MBC/MIC \\
V. parahaemolyticus & $29.8 \pm 0.8$ & $0 \pm 0$ & 1.25 & 2.50 & 1 \\
V. parahaemolyticus (EMS/AHPND) & $18.0 \pm 2.3$ & $0 \pm 0$ & 2.50 & 5.00 & 2 \\
V. fluvialis & $28.0 \pm 0.7$ & $0 \pm 0$ & 0.31 & 0.63 & 2 \\
V. vulnificus & $27.6 \pm 0.5$ & $0 \pm 0$ & 1.25 & 1.25 & 2 \\
V. alginolyticus & $27.1 \pm 0.8$ & $0 \pm 0$ & 0.63 & 2.50 & 1 \\
V. mimicus & $27.6 \pm 0.5$ & $0 \pm 0$ & 0.31 & 0.63 & 4 \\
V. harveyi & $21.3 \pm 2.1$ & $0 \pm 0$ & 2.50 & 5.00 & 2 \\
\hline
\end{tabular}

Note: Growth inhibition zone (mm.); Resistant: $\leq 9 \mathrm{~mm}$; Intermediate: $\geq 10-13 \mathrm{~mm}$; Susceptible: $\geq 14 \mathrm{~mm}$ (Lorian, 1995 in Oonmetta - aree et.al., 2006), Data in table, Average \pm SD.

As reported by Canillac \& Mourey (2001), if the MBC/MIC ratio is found to be less than or equal to 4, the strain is considered to be susceptible; on the other hand, if this ratio is greater than 4 , the strain is considered to be tolerant. 
The results showed a growth inhibition zone surrounding the galangal extract disc of all species' bacteria. The MBC and MIC of 2 bacterial species, $V$. cholerae and $V$. vulnificus, showed the highest degree of sensitivity. The other 5 species, $V$. parahaemolyticus, $V$. parahaemolyticus (EMS/AHPND), V. fluvialis, V. mimicus, and $V$. harveyi, showed intermediate sensitivity, and $V$. alginolyticus showed low sensitivity among the bacteria tested. The results of the antibacterial activity of the galangal extract in this study showed most of the species of Vibrio spp. to be sensitive (Table 1).

\subsection{Fungi Isolation and Identification}

Pathogenic fungi were isolated from L. vannamei, feces, and artificial feed. All fungi were identified by the 6 species shown in Table 2.

Table 2. The 6 species of fungi isolated from the hepatopancreas and intestines of shrimp naturally infected with white feces syndrome L. vannamei, and from artificial feed

\begin{tabular}{ll}
\hline Fungi species & \multicolumn{1}{c}{ Source of isolated } \\
\hline Aspergillus flavus & Hepatopancreas, intestine, and artificial feed \\
Aspergillus ochraceus & Hepatopancreas and artificial feed \\
Aspergillus japonicus & White feces and artificial feed \\
Penicillium sp. & Hepatopancreas and intestine \\
Fusarium sp. & Hepatopancreas, intestine, and artificial feed \\
Cladosporium cladosporioides & Intestine \\
\hline
\end{tabular}

\subsection{Efficacy of the Extract against Pathogenic Fungi}

Table 3 shows the efficacy of the galangal extract on 6 species of fungi. The galangal extract at a concentration of $0.5 \mathrm{mg} / \mathrm{ml}$ represented the strongest inhibition of $A$. ochraceus. A concentration of $1 \mathrm{mg} / \mathrm{ml}$ inhibited the growth of Penicillium sp.; Fusarium sp., and C. cladosporioides. Two species, A. flavus and A. japonicus, were least susceptible to the galangal extract $(8 \mathrm{mg} / \mathrm{ml})$.

Table 3. Efficacy of the galangal extract on the growth inhibition of fungi (\%) isolated from an infection of white feces syndrome pathogen L. vannamei and from artificial feed

\begin{tabular}{lllllll}
\hline \multirow{2}{*}{$\begin{array}{l}\text { Extract Concentration } \\
(\mathrm{mg} / \mathrm{ml})\end{array}$} & \multicolumn{5}{c}{ The growth inhibition of fungi (\%) } \\
\cline { 2 - 7 } & A. flavus & A. ochraceus & A. japonicus & Penicillium sp. & Fusarium $\mathrm{sp}$. & C. cladosporioides \\
\hline 0.0005 & $6.12 \pm 5.77$ & $0.00 \pm 0.00$ & $0.00 \pm 0.00$ & $0.00 \pm 0.00$ & $0.00 \pm 0.00$ & $6.67 \pm 6.29$ \\
0.005 & $16.33 \pm 2.89$ & $6.82 \pm 2.50$ & $18.64 \pm 9.59$ & $0.00 \pm 0.00$ & $4.23 \pm 1.48$ & $17.05 \pm 11.25$ \\
0.05 & $48.98 \pm 14.43$ & $18.18 \pm 9.28$ & $15.25 \pm 0.00$ & $16.67 \pm 0.00$ & $27.95 \pm 12.58$ & $40.00 \pm 3.14$ \\
0.5 & $56.73 \pm 2.89$ & $100.00 \pm 0.00$ & $25.42 \pm 4.79$ & $56.23 \pm 15.89$ & $42.35 \pm 19.49$ & $51.11 \pm 6.29$ \\
1 & $77.55 \pm 31.75$ & $100.00 \pm 0.00$ & $37.29 \pm 1.15$ & $100.00 \pm 0.00$ & $100.00 \pm 0.00$ & $100.00 \pm 0.00$ \\
2 & $77.55 \pm 31.75$ & $100.00 \pm 0.00$ & $57.63 \pm 11.98$ & $100.00 \pm 0.00$ & $100.00 \pm 0.00$ & $100.00 \pm 0.00$ \\
4 & $82.66 \pm 49.06$ & $100.00 \pm 0.00$ & $55.93 \pm 9.59$ & $100.00 \pm 0.00$ & $100.00 \pm 0.00$ & $100.00 \pm 0.00$ \\
8 & $100.00 \pm 0.00$ & $100.00 \pm 0.00$ & $100.00 \pm 0.00$ & $100.00 \pm 0.00$ & $100.00 \pm 0.00$ & $100.00 \pm 0.00$ \\
\hline
\end{tabular}

Note: Data in table, Average \pm SD.

\subsection{Effect of the Galangal Extract against Vibrio spp. and Fungi}

\subsubsection{Health Status of the Naturally infected Shrimp}

The hepatopancreas and intestines of shrimp from a grow-out pond that were infected with white feces syndrome were observed, and 4 species of fungi were found including C. cladosporioides, Penicillium sp., A. japonicus, and Fusarium spp. In addition, a rather high incidence of Vibrio spp. were also isolated from the same samples $(100.0 \pm 0.0 \%)$. The total counts from the hepatopancreas and intestines were as high as $386.73 \pm 323.73 \times 10^{3}$ $\mathrm{cfu} / \mathrm{g}$ and $426.46 \pm 168.21 \times 10^{5} \mathrm{cfu} / \mathrm{g}$, respectively. The dominant numbers of Vibrio spp. isolated in the feces were green and yellow colonies. 


\subsubsection{Effect of the Galangal Extract on the Total Number of Vibrio spp.}

The totals for the number of Vibrio spp. in the hepatopancreas and intestines of infested L. vannamei shrimp fed the galangal extract (treated diet) were significantly less than that for the control group $(P<0.05)$. Figure 1 lists the numbers after 3 days in the hepatopancreas (A) and 5 days in the intestines (B) after feeding with the treated diet. In contrast, the total number of Vibrio spp. in the hepatopancreas (A) and intestines (B) of the control group had increased through 12 days (Figure 1). No green colonies of Vibrio spp. were found in either of the groups fed 2 or $4 \%$ treated diets.

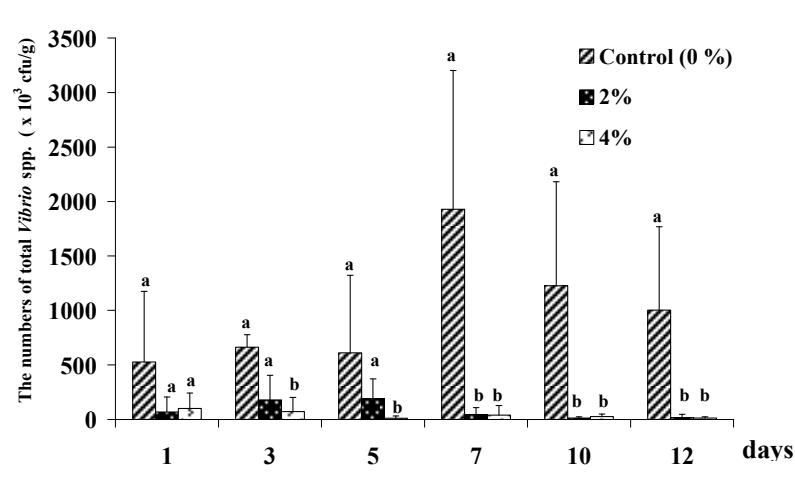

(A) Hepatopancreas

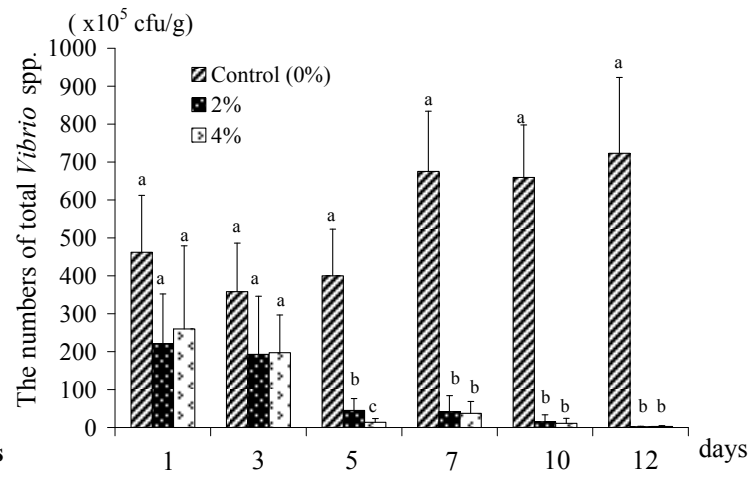

(B) Intestines

Figure 1. The total number of Vibrio spp. in (A) hepatopancreas and (B) intestines of infested L. vannamei fed the 2 and $4 \%$ galangal extract, as well as the control $(0 \%)$, for 12 days. Data are the means $\pm \mathrm{SD}$; different letters for the time interval indicates a significant difference $(P<0.05)$

\subsubsection{Effect of the Galangal Extract on Pathogenic Fungi}

The incidence of fungi infestation in the hepatopancreas and intestines of infested $L$. vannamei shrimp fed the crude galangal extract (treated diet) was significantly lower than that in the control group $(P<0.05)$. Also, no fungi could be found in the hepatopancreas and intestines of white shrimp after feeding with the treated diet for 10 to 12 days (Figure 2 (A) and (B)).

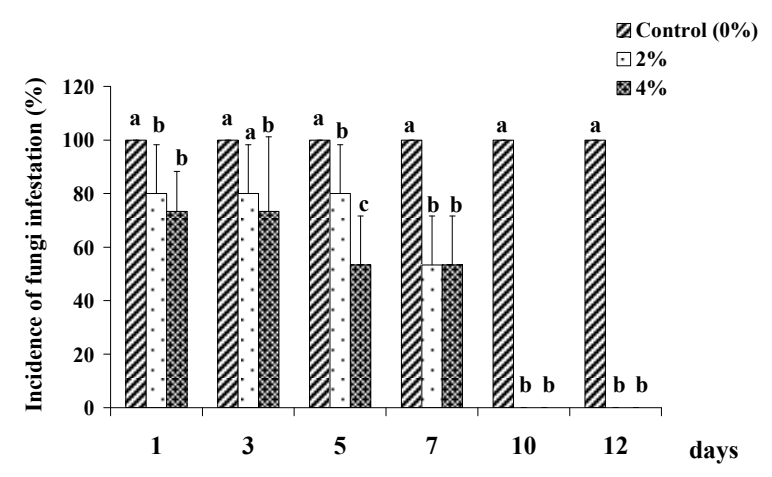

(A) Hepatopancreas

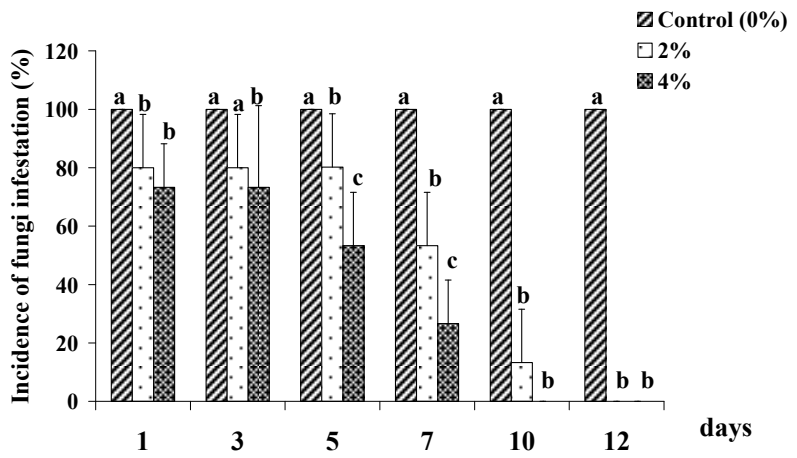

(B) Intestines

Figure 2. Incidence of fungi infestation (\%) in the hepatopancreas (A) and intestines (B) of infested L. vannamei fed galangal extract at 2 and $4 \%$, along with that of the controls $(0 \%)$, for 12 days. Data are the means \pm SD; different letters for the time interval indicates a significant difference $(P<0.05)$

\subsection{Effect of the Galangal Extract on Disease Resistance Challenged by V. parahaemolyticus (EMS/AHPND)}

The survival rates for shrimp fed 2 and $4 \%$ galangal extract were $73.3 \pm 5.8 \%$ and $83.3 \pm 5.8 \%$, respectively. Only $16.7 \pm 5.8 \%$ of the survival shrimp were from the control group ( $0 \%$ galangal extract). The results differed significantly between the treated groups and the control group $(P<0.05)$. Obviously, shrimp fed the galangal extract at $4 \%$ had the highest survival rate (Figure 3). 


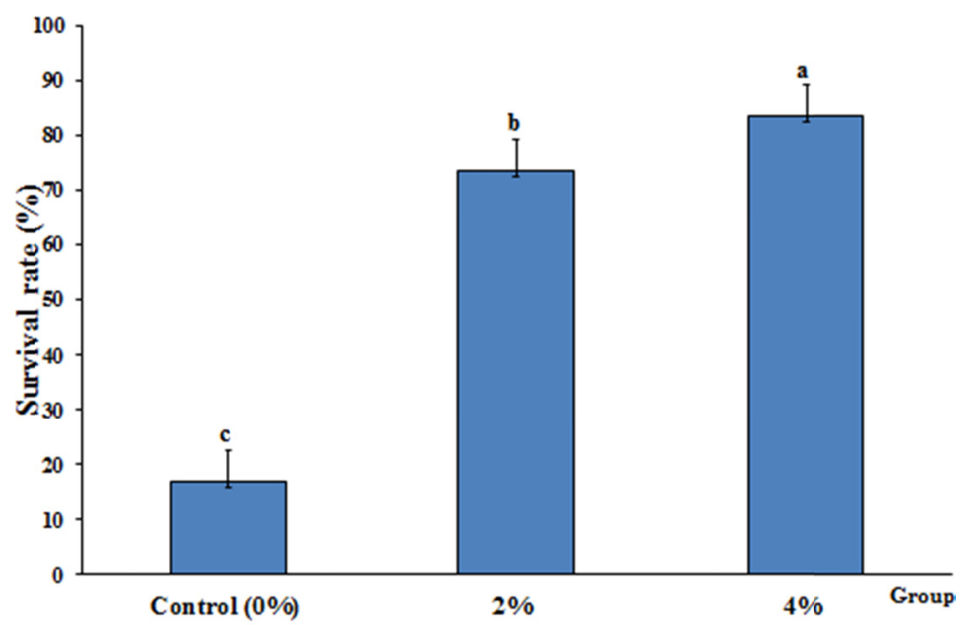

Figure 3. The survival rate of $L$. vannamei shrimp fed diets containing 2 and $4 \%$ of galangal extract (treated diet) and $0 \%$ (control) following 12 days of feeding trials prior to being challenged with V.parahaemolyticus

(EMS/AHPND). Different letters indicate a significant difference $(P<0.05)$

\section{Discussion}

Investigation into the bacteria that are important and common in the aquatic environment of EMS/AHPND has been used to develop a safe and environmentally friendly product in shrimp aquaculture via alternative methods to control and treat vibrios diseases. The essential oil of crude galangal extract is a candidate for such a product since many researchers have documented its antimicrobial activities (de Pooter et al., 1985; Thomas et al., 1996; Turker et al., 2002; Oonmetta-areea et al., 2006; Tachakittirungrod \& Chowwanapoonpohn, 2007; Vuddhakul et.al., 2007; Mayachiew \& Devahastin, 2008; Latha et al., 2009; Rao et al., 2010). Canillac \& Mourey (2001) reported that strains of vibrios with an $\mathrm{MBC} / \mathrm{MIC}$ ratio of less than or equal to 4 are considered to be susceptible to the extract, and if the ratio is greater than 4 a strain is considered to be tolerant of the extract. Based on our results, the MBC/MIC ratios showed that 8 species of Vibrio were sensitive to the extract. The results also revealed that the extract inhibited the growth of $V$. harveyi. Also, the ethanol galangal extract in this study was considered to be antibacterial against $V$. parahaemolyticus (EMS/AHPND), which is a causative agent of a recently recognized serious disease in Southeast Asia (Lightner et al., 2012; NACA FAO, 2011; Bondad-Reantaso et al., 2012). Ethanol extract of galangal containing 1'-acetoxyeugenol acetate (ACA) as a main ingredient could inhibit the growth of Gram-positive bacteria such as Staphylococcus cerevisiae, S. epidermidis, S. aureus and Bacillus cereus, but it did not inhibit the growth of Gram-negative bacteria such as Salmonella spp., Escherichia coli, and Enterobacter aerogenes (Oonmetta-aree et al., 2006). The ingredients in this herb, 1'-acetoxychavicol acetate, ACA and eugenol, are effective for the treatment of inflammation and fungal diseases on human skin, and they inhibit the growth of Escherichia coli (De Pooter et al., 1985; Kubo et al., 1991; Norajit et al., 2007; Natta et al., 2008; Chudiwal et al., 2010). Furthermore, V. parahaemolyticus growth is inhibited by the chloroform extract of fresh galangal root, but not by the methanol extract (Vuddhakul et. al., 2007).

These studies were carried out to determine the fungal species that are isolated from the hepatopancreas and intestine of white feces syndrome L. vannamei and from artificial feed. Among these species, Fusarium sp. were observed more frequently than the others. The study was focused on the degree that galangal crude extract inhibited the growth of these pathogenic fungi. De Silava et al. (2011) isolated 18 fungi species from L. vannamei, and among those, Aspergillus flavus and 2 species of A. parasiticus were able to produce aflatoxin B1. Contamination of F. moniliforme (Li et al., 1994) and A. flavus (Lighter, 1993) was reported in raw materials used to produce commercial pellet feed. Yulia (2005) previously reported that the ethanol extract of galangal rhizomes was the most effective in reducing spore germination of the fungi. Furthermore, this extract also inhibited the colony areas of $F$. moniliforme, A. flavus and A. niger (Handajani \& Purwoko, 2008). This study's results also showed the growth inhibition of fungi by crude galangal extract. The study found fungi that produce alflatoxin to be few in number in artificial feed, which may be due to moisture retention during transport or storage on the farm. To prevent fungi in feed, it should be kept in a dry place and it should not be expired.

Our tests on the inhibition of Vibrio spp. and fungi in vitro and in vivo returned similar results. The infected shrimp fed the galangal extract diets had a lower number of Vibrio spp. and fungi compared with the control group. It is 
remarkable that the galangal extract could be used to inhibit growth and reduce the number of Vibrio spp. and fungi that cause white feces syndrome and AHPND in shrimp. In the present study, after shrimp were fed a diet mixed with 2 and $4 \%$ of the extract with ethanol, from day 1 the numbers of Vibrio spp. in the hepatopancreas and intestines were lower than in the control group. Remarkably, galangal extract can be used to inhibit the growth and reduce the number of Vibrio spp. and fungi to prevent white feces syndrome. Moreover, resistance in L. vannamei against $V$. parahaemolyticus causing AHPND occurred when the shrimp were fed a diet mixed with galangal extract at 2 or $4 \%$ for 12 days. Our results also showed a higher survival rate $(83.3 \%)$ of the treatment group (fed with $4 \%$ galangal extract) than the control group (feeding with $0 \%$ extract). The results revealed the efficiency of the extract, which has ability to inhibit $V$. parahaemolyticus (EMS/AHPND), and it may stimulate the immune system in the tested shrimp (Chaweepack et al., 2015). Therefore, shrimp fed galangal extract diet are healthier than the control group, and shrimp fed a galangal extract diet could resist infection well. For several years, antibiotics and some hazardous chemicals have been used to treat pathogenic agents in the aquaculture industry, particularly in intensive shrimp-farming systems. The development of resistant bacteria and residue in shrimp caused a major obstacle to trade and had a negative impact on the environment as well as on consumer health. The use of herbal medicines is a viable alternative to the overuse of antibacterial agents. The main advantage of herbal agents is that the crude extract contains a mixture of compounds such as phenols, acids, esters, and aldehydes, to which bacteria are unlikely to develop resistance. A synthetic agent that contains a single compound, however, is easier for bacterial stains to resist (Abraham et al., 1997). Based on the results of the present study, we recommend alternative methods for control of the disease that causes white feces syndrome and AHPND in the shrimp industry by using galangal crude extract, which has proven to be effective and safe for the environment as well as for consumers.

\section{Conclusion}

This investigation was focused on the efficacy of galangal extract for treatment of the pathogenic organisms that cause white feces syndrome and AHPND in Pacific white shrimp, L. vannamei. Ethanol galangal extract exhibited the highest potential for Vibrio spp. and fungi reduction. The highest percentage (4\%) of ethanol extract was most effective in reducing all species of the pathogens of $V$. parahaemolyticus (EMS/AHPND). Therefore, galangal extract should be used as an antimicrobial for white feces syndrome and AHPND therapeutics in Pacific white shrimp L. vannamei and in shrimp cultures. This alternative method could assist in reducing the impact of antibiotic or chemical residue in shrimp products as well as helping to reduce the presence of resistant bacterial strains in the environment.

\section{Acknowledgments}

This research was supported by the Department of Fisheries (DOF), Agriculture Research Development Agency (ARDA), Ministry of Agriculture and Cooperatives of Thailand and the Kyoto Institute of Technology (KIT), Japan.

\section{References}

Abraham, T., Manley, J. R., Palaniappan, R., \& Devendran, K. (1997). Pathogenicity and antibiotic sensitivity of luminous Vibrio harveyi isolated from diseased penaeid shrimp. J Aquac Trop., 12(1), 1-8.

Bondad-Reantaso, M.G., Subasinghe, R.P., Josupeit, H., Cai, J., \& Zhou, X. (2012). The role of crustacean fisheries and aquaculture in global food security: past, present and future. J Invertebr Pathol., 110, 158-165. http://dx.doi.org/10.1016/j.jip.2012.03.010

Canillac, N., \& Mourey, A. (2001). Antibacterial activity of the essential oil of Picea excels on Listeria, Staphylococcus aureus and coliform bacteria. Food Microbiology, 18, 261-268. http://dx.doi.org/10.1006/ fmic. 2000.0397

Chaweepack, T., Chaweepack, S., Muenthaisong, B., Ruangpan, L., Nagata, K., \& Kamei, K. (2015). Effect of galangal (Alpinia galanga Linn.) extract on the expression of immune-related genes and Vibrio harveyi resistance in Pacific white shrimp (Litopenaeus vannamei). Aquacult Int., 23(1), 385-399. http://dx.doi.org/10.1007/s10499-014-9822-2

Chudiwal, A. K., Jain, D. P., \& Somani, R. S. (2010). Alpinia galangal Wild.-An overview on phyto-pharmacological properties. Indian Journal of Natural Products and Resources, 1(2), 143-149.

Colwell, R. R. (1984). Vibrios in the environment. Wiley, New York. 
de Pooter, H. L., Omar, M. N., Coolaset, B. A., \& Schamp, N. M. (1985). The essential oil of greater galanga (Alpinia galanga) from Malaysia. Phytochemistry., 24, 93-96. http://dx.doi.org/10.1016/S0031-9422 (00)80814-6

de Silva, L. R. C., de Souza, O. C., dos Santos Fernandes, M. J., Débora, M. M., Lima, D. M. M., Coelho, R. R. R., \& Souza-Motta, C. M. (2011). Culturable Fungal Diversity of shrimp Litopenaeus vannamei Boone from Breeding frams in Brazil. Brazilian Journal of Microbiology, 42, 49-56.

Flegel, T. W. (2012). Historic emergence, impact and current status of shrimp pathogens in Asia. Journal of Invertebrate Pathology, 110(2), 166-173. http://dx.doi.org/10.1016/j.jip.2012.03.004

Handajani, N. S., \& Purwoko, T. (2008). The activity of galanga (Alpinia galanga) rhizome extract against the growth of filamentous fungi Aspergillus spp. that produce aflatoxin and Fusarium moniliforme. Biodiversitas., 9, 161-164. http://dx.doi.org/10.13057/biodiv/d090301

Joshi, J., Srisala, J., Hong, V. T., Chen, I. T., Nuangsaeng, B., Suthienkul, O., ... Thitamadee, S. (2014). Variation in Vibrio parahaemolyticus isolates from a single Thai shrimp farm experiencing an outbreak of acute hepatopancreatic necrosis disease (AHPND). Aquaculture, 428-429, 297-302. http://dx.doi.org/10.1016/j.aquaculture.2014.03.030

Karunasagar, I. D., Karunasagar, I. N., \& Umesha, R. K. (2004). Microbial Diseases in Shrimp Aquaculture. Marine Microbiology. In N. Ramaiah (Ed.), National Institute of Oceanography, Goa India. Facets \& Opportunities (pp. 121-134).

Khomvilai, C. (2006). Application of sodium hypochlorite as an antifungal agent to aquaculture in Japan and Thailand (Unpublished doctoral dissertation). Mie University, Japan.

Klich, M. A. (2002). Identification of common Aspergillus species. CBS. The Netherlands.

Latha, C., Shriram, V. D., Jahagirdar, S. S., Dhakephalkar P. K., \& Rojatkar, S. R. (2009). Antiplasmid activity of 1 '-acetoxychavicol acetate from Alpinia galanga against multi-drug resistant bacteria. Ethnopharmacology, 123, 522-525. http://dx.doi.org/10.1016/j.jep.2009.03.028

Lee, S. W., Najiah, M., Wendy, W., \& Nadirah, M. (2009). Comparative study on antibiogram of Vibrio spp. isolated from diseased postlarval and marketable-sized white leg shrimp (Litopenaeus vannamei). Front Agric China, 3, 446-451. http://dx.doi.org/10.1007/s11703-009-0068-0

Li, M. H., Raverty, S. A., \& Robinson, E. H. (1994). Effect of dietary mycotoxins produced by the mold Fusarium moniliforme on channel catfish Ictalurus punctatus. J.World Aquacult. Soc., 25(4), 512-516. http://dx.doi.org/10.1111/j.1749-7345.1994.tb00820.x

Lightner, D. V. (1993). Diseases of culture Penaeid shrimp. In J. P. McVey (Ed.), CRC Handbook of Mariculture: Crustacean Aquaculture (pp. 455-474)( ed.) CRC Press. BocaRaton.

Lightner, D. V., Redman, R. M., Pantoja, C. R., Noble, B. L., \& Tran, L. H. (2012). Early mortality syndrome affects shrimp in Asia. Glob Aquacult Advocate., Jan/Feb 2012, 40.

Mayachiew, P., \& Devahastin, S. (2008). Antimicrobial and antioxidant activities of Indian gooseberry and galangal extracts. Food Science and Technology, 41, 1153-1159. http://dx.doi.org/10.1016/j.lwt.2007.07.019

Montero, A. B., \& Austin, B. (1999). Characterization of extracellular products from an isolate of Vibrio harveyi recovered from diseased post-larval Penaeus vannamei (Bonne). Journal of Fish Diseases, 22, 377-386. http://dx.doi.org/10.1046/j.1365-2761.1999.00189.x

NACA-FAO (Network of Aquaculture Centers in Asia-Pacific-Food and Agriculture Organization of the United Nations). (2011). Quarterly aquatic animal diseasereport (Asia and Pacific Region), 2011/2, April-June 2011. NACA, Bangkok

Oonmetta-aree, J., Suzuki, T., Gasaluck, P., \& Eumkeb., G. (2006). Antimicrobial and action of galangal (Alpinia galanga Linn.) on Staphylococus aureus. Food Science and Technology., 39, 959-965. http://dx.doi.org/ 10.1016/j.lwt.2005.06.015

Rao, K., Ch, B., Narasu, L. M., \& Giri, A. (2010). Antibacterial Activity of Alpinia galangal (L) Willd Crude Extracts. Appl Biochem Biotechnol., 162, 871-884. http://dx.doi.org/10.1007/s12010-009-8900-9

Raper, K. B., \& Fennell, D. I. (1965). The genus Aspergillus. The Williams \& Wilkins Company, Baltimore.

Ruangpan, L., \& Kitao, T. (1991). Vibrio bacteria isolated from black tiger shrimp Penaeus monodon Fabricius. J Fish Dis., 14, 383-388. http://dx.doi.org/10.1111/j.1365-2761.1991.tb00836.x 
Ruangpan, L., Thanasomwang, V., \& Sangrungrauge, K. (1997). Bacteria in Black tiger Shrimp pond farming development Systems. The Proceeding of $35^{\text {th }}$ Kasetsart University Annual Conference. Thailand., 3-10.

Samson, R. A., \& Hoekstra, E. S. (1994). Common fungi occurring in indoor environments. In R. A. Samson (Ed.), Health Implications of Fungi in indoor environments (pp. 541-587). Elsevier, Amsterdam.

Samson, R. A., Hoekstra, E. S., Frisvad, J. C., \& Filtenborg, O. (1995). Introduction to Food-borne Fungi. CBS, the Netherlands.

Sung, H. H., Hsu, S. F., Chen, C. K., Ting, Y. Y., \& Chao, W. L. (2001). Relationships between disease outbreaks in cultured tiger shrimp (Penaeus monodon) and composition of Vibrio communities in pond water and shrimp hepatopancreas during cultivation. Aquaculture., 192, 101-110. http://dx.doi.org/10.1016/S0044 -8486(00)00458-0

Tachakittirungrod, S., \& Chowwanapoonpohn, S. (2007). Comparison of Antioxidant and Antimicrobial activities of Essential Oils from Hyptis suaveolens and Alpinia galangal Growing in Northern Thailand, CMU, J Nat Sci., 6, 31-42.

Tangtrongpiros, J. (2010). Chula Researcher Unveils Groundbreaking Study On Disease Killing Off Cultured Shrimp. Preventive approaches proposed to avert business losses in national shrimp farming industry. The Gazette of Chulalongkorn University, Thailand, 2, 3.

Thomas, E., Shanmugan, J., \& Rafi, M. M. (1996). Antibacterial activity of plants belonging to Zingiberaceace family. Biomedicine., 16, 15-20.

Tran L., Nunan, L., Redman, R. M., Mohney, L. L., Pantoja, C.R., Fitzsimmons, K., \& Lightner, D. V. (2013). Determination of the infectious nature of the agent of acute hepatopancreatic necrosis syndrome affecting penaeid shrimp. Dis Aquat Org., 105, 45-55. http://dx.doi.org/10.3354/dao02621

Turker, A., \& Usta, C. (2002). Biological activity of some medicinal plants sold in Turkish Health-food stores. Biodiversity Ecosyst., 34(19), 105-113.

Vandenberghe, J., Verdonck, L., Robles-Arozarena, R., Rivera, G., Blland, A., Balladares, M., Gomez-Gil, B., Calderon, J., Sorgeloos, P., \& Swings, J. (1999). Vibrios Associated with Litopenaeus vennamei Larvae, Postlarvae, Broodstock, and Hatchery Probionts. Applied and Environmental Microbiology., 65, 2592-2597.

Vuddhakul, V., Bhoopong, P., Hayeebilan, F., \& Subhadhirasakul, S. (2007). Inhibitory activity of Thai condiments on pandemic strain of Vibrio parahaemolyticus. Food Microbiology., 24, 413-418. http://dx.doi.org/10.1016/j.fm.2006.04.010

Yulia, E. (2005). Antifungal activity of plant extracts and oils against fungal pathogens of pepper (Piper nigrum L.), cinnamon (Cinnamomum zeylanicum Blume.), and turmeric (Curcuma domestica Val.). Thesis of Master of Science the School of Tropical Biology, James Cook University, Australia.

\section{Copyrights}

Copyright for this article is retained by the author(s), with first publication rights granted to the journal.

This is an open-access article distributed under the terms and conditions of the Creative Commons Attribution license (http://creativecommons.org/licenses/by/3.0/). 